\title{
Yeast Transformant-Based Glucose Biosensor for Implantable Application
}

\author{
Masaki Yamaguchi*, Atsunori Nakano ${ }^{1}$ and Tadayoshi Taniyama² \\ Faculty of Engineering, Iwate University, 4-3-5 Ueda, Morioka 020-8551, Japan \\ ${ }^{1}$ Graduate School of Science and Engineering for Research, University of Toyama, \\ 3190 Gofuku, Toyama 930-8555, Japan \\ ${ }^{2}$ Laboratory of Bacterial Infection and Immunity, Department of Immunology, \\ National Institute of Infectious Diseases, 1-23-1 Toyama, Shinjuku-ku, Tokyo 162-8640, Japan
}

(Received February 8, 2008; accepted May 8, 2008)

Key words: $\quad$ biosensor, glucose oxidase, transformant, A. niger, P. pastoris, totally implantable type

A novel transformant-based glucose biosensor is proposed using glucose oxidase (GOD) as the molecular recognition material in order to solve the problem of deactivation of the enzyme with time. In this paper, the feasibility of this approach for a glucose biosensor is demonstrated as a preliminary study. A. niger is used as a source of the GOD gene. The yeast strain P. pastoris $\mathrm{X}-33$ is used as the host for plasmid construction, cloning, and enzyme expression. The yeast transformant-based glucose biosensor consists of a ring filter, disc housings, and a flat electrode (30 mm diameter, $8.5 \mathrm{~mm}$ thick). A reaction chamber with an inner volume of $300 \mu \mathrm{l}$ is constructed by sandwiching a ring filter made of porous sintered metal between two disc housings. Both the GOD protein and its transformant are enclosed in the reaction chamber. Our results indicated that (i) the GOD gene transformant, which is capable of not only secretory expression but also constitutive expression, was obtained, and (ii) deactivated GOD, with time, can be replaced with newly produced recombinant GOD from the GOD gene transformant.

\section{Introduction}

Despite many technological advances in biosensor research and the development and introduction of many different products, glucose biosensors still account for approximately $85 \%$ of the current world market for biosensors, which has recently been established to be around $\$ 5$ billion. ${ }^{(1)}$ The main application of the glucose biosensor is as blood glucose monitors for diabetics. The most commonly used enzymes in the design of glucose biosensors contain redox groups that change in redox state during biochemical reaction. Enzymes of this type are glucose oxidase (GOD) and glucose dehydrogenase (GDH). GOD (oxygen 1-oxidoreductase, EC 1.1.3.4) catalyzes the oxidation of $\beta$-D-glucose

*Corresponding author: e-mail: masakiy@iwate-u.ac.jp 
to D-glucono- $\delta$-lactone and hydrogen peroxide using molecular oxygen as an electron acceptor. ${ }^{(2)}$

Either subcutaneously implantable-type (needle or cannula-shaped configuration) ${ }^{(3-5)}$ or totally implantable type ${ }^{(6-10)}$ glucose biosensors have been investigated for continuous real-time measurement of blood glucose level. Implantation of up to 50 days has already been attempted.(11) However, conventional blood glucose monitors in commercial use have a disadvantage in that they cannot perform continuous measurements for a period of more than 3 days. ${ }^{(12)}$ A totally implantable enzyme-based glucose biosensor has the following problems: (i) deactivation of the enzyme with time, (ii) difficulty to prove the biosafety of the enzyme immobilising materials, and (iii) decrease in sensitivity owing to adhesion of proteins onto the surface of the electrode. ${ }^{(13,14)}$ As an approach to solving these problems, some biocompatible materials have been proposed for providing interfaces for biosensors by decreasing the number of adherent cells. ${ }^{(15)}$ Recently, a new concept for totally implantable-type biosensors has been proposed which focuses on inherent fluorescence from single-walled carbon nanotubes. ${ }^{(16)}$

In order to solve deactivation of the enzyme with time, the authors propose a novel transformant-based glucose biosensor fabricated using GOD as the molecular recognition material, which is produced by a GOD gene transformant. In this transformant-based glucose biosensor, both the GOD protein and GOD gene transformant are enclosed in a small reaction chamber with a volume of $300 \mu \mathrm{l}$. The deactivated GOD, with time, can be replaced with a newly produced recombinant GOD from the GOD gene transformant.

In order to make this totally implantable glucose biosensor feasible, a GOD gene transformant needs to be obtained so that continuous production of GOD is possible. The GOD gene from A. niger (A. niger) has been cloned from both cDNA and genomic libraries using oligonucleotide probes derived from the amino acid sequences of peptide fragments of the enzyme $(1,818 \mathrm{bp}) \cdot{ }^{(17-20)}$ The GOD gene has also been isolated from Saccharomyces cerevisiae. ${ }^{(21-23)}$ Furthermore, the GOD gene linked to a secretory expression sequence has also been identified. ${ }^{(24)}$

In this paper, we present a transformant cell incorporating the GOD gene (GOD gene transformant), which is capable of constitutive as well as secretory expression, using the yeast strain $P$. pastoris (P. pastoris) X-33. Time-course changes in GOD activity are compared between recombinant GOD produced by the GOD gene transformant and commercially available GODs. The detected current characteristics of the transformantbased glucose biosensor that enclosed recombinant GOD are examined. Finally, the feasibility of a totally implantable glucose biosensor is discussed on the basis of these results.

\section{Materials and Methods}

\subsection{GOD gene transformant}

\subsubsection{Strain, plasmid and culture}

A. niger was used as a source of the GOD gene. A. niger was obtained from the American Type Culture Collection (ATCC; strain No. 9029). A. niger was grown in ATCC medium (No. 325; 2\% malt extract, 2\% peptone; Becton, Dickinson and Company, France) containing $2 \%$ glucose at $24^{\circ} \mathrm{C}$. 
The yeast strain $P$. pastoris $\mathrm{X}-33$ (wild type; Invitrogen Corporation, CA, USA) was used as a host for plasmid construction, cloning, and enzyme expression. ${ }^{(25)}$ The cells are spheroidal to ovoidal, $(2.0-4.0) \times(2.2-5.8) \mu \mathrm{m}^{2}$, and occur singly or in pairs. ${ }^{(26)}$ $P$. pastoris X-33 was grown in YPD medium (1\% yeast extract, $2 \%$ peptone; Becton, Dickinson and Company, France) containing $2 \%$ glucose at $30^{\circ} \mathrm{C}$. Plasmid pGAPZaC (3,152 bp, Invitrogen Corporation, CA, USA) was used as a cloning vector. The pGAPZ $\alpha \mathrm{C}$ is a Pichia expression vector for constitutive expression and purification of recombinant proteins in P. pastoris. ${ }^{(27)}$ The vector has Zeocin resistance as a selectable marker of expression vectors. Zeocin is an antibiotic that acts as a strong antibacterial and antitumor drug. ${ }^{(28)}$ In addition, the vector produces secretory expression as it codes for an $\alpha$-factor secretion signal.

\subsubsection{DNA manipulation, ligation, and transformation}

Aspergillus chromosomal DNA was isolated using a DNA extraction kit (No. 314-02731; Nippon Gene Co., Ltd., Japan). ${ }^{(29)}$ A two-step polymerase chain reaction (PCR) was carried out using oligonucleotide primers as follows: First PCR: 5'-CCTTTCCTC TCTCATTCCCTCA-3' and 5'-AATGCCCTTGTTTGGTAGTAAT-3'. Second PCR: 5' -atccatcgatGAGCCAATGGCATTGAAGCCAGCCTCCT-3' and 5'-attagcggccgcCTAC ATGGAAGCATAATCTTCCAAGATAG-3', where atccatcgatg is the Bsu15I restriction enzyme site and attagcggccgc is the NotI restriction enzyme site.

Electrophoresis was carried out using $\lambda$-EcoI14I as a molecular weight marker according to Sambrock et al. ${ }^{(30)}$ The nucleotide sequence was analyzed using a sequencer (ABI Prism 3100 Genetic Analyzer, Applied Biosystems, CA, USA). The identified GOD gene $(1,818 \mathrm{bp})$ was ligated to the plasmid vector pGAZ $\alpha \mathrm{C}$ using a DNA ligation kit (Code: 6023, Takara Bio Inc., Japan).(31)

The ligated DNA was used to transform $P$. pastoris X-33 to obtain a GOD gene transformant. Yeast transformations were performed according to Neumann et al. ${ }^{(32,33)}$ by electroporation (Gene Pulser II system, Bio-Rad Laboratories, CA, USA). Transformants were grown in a selective medium (YPD medium containing $0.03 \%$ Zeocin) in order to acquire the GOD gene transformant.

\subsubsection{GOD assay}

$\beta$-D-glucose was used as the substrate of GOD, and GOD activity was measured by an absorbance-based technique according to the following reactions;

GOD:

peroxidase:

$$
\beta \text {-D-glucose }+\mathrm{O}_{2}+\mathrm{H}_{2} \mathrm{O} \rightarrow \text { D-Glucono- } \delta \text {-lactone }+\mathrm{H}_{2} \mathrm{O}_{2}
$$

$$
2 \mathrm{H}_{2} \mathrm{O}_{2}+4 \text {-aminoantipyrine }+ \text { phenol } \rightarrow \text { quinoneimine dye }+4 \mathrm{H}_{2} \mathrm{O}
$$

The appearance of quinoneimine dye formed by coupling of 4-aminoantipyrine and phenol was determined at $500 \mathrm{~nm}$ using a spectrophotometer $\left(O D_{500}\right.$, Hitachi, Japan). The change in absorbance was analyzed at $37^{\circ} \mathrm{C}$. One unit activity (U) per volume of enzyme solution (ml) is defined as the activity that produces $1 \mu \mathrm{mol}$ of $\beta$-D-glucose per minute. 


\subsection{Transformant-based glucose biosensor}

A transformant-based glucose biosensor used for the analysis of glucose concentration consists of a ring filter, disc housings, and a flat electrode (Fig. 1; 30 $\mathrm{mm}$ diameter, $8.5 \mathrm{~mm}$ thick). A reaction chamber with an inner volume of $300 \mu \mathrm{l}$ is constructed by sandwiching a ring filter made of porous sintered metal (stainless steel, outside diameter of $19 \mathrm{~mm}$, pore size of $0.6 \mu \mathrm{m}$ ) between two disc housings (polycarbonate). A working electrode (WE, platinum, $2.54 \mathrm{~mm}^{2}$ area, $0.4 \mu \mathrm{m}$ thick), a counter electrode (CE, platinum, $0.4 \mu \mathrm{m}$ thick), and a pseudoreference electrode (RE, $\mathrm{Ag} / \mathrm{AgCl}, 1.0 \mu \mathrm{m}$ thick) are fabricated as a flat electrode $\left(10 \times 7 \times 1 \mathrm{~mm}^{3}\right.$, base plate: glass) concentrically on the same planar surface by sputtering. The flat electrode is soaked in $100 \mathrm{mM} \mathrm{NaCl}$ solution, and a part of $\mathrm{Ag}$ of the pseudo-reference electrode is chlorinated to $\mathrm{AgCl}$ at $+100 \mu \mathrm{A}$ for $5 \mathrm{~s}$ using a galvanostat (No.1112, BAS Inc., Japan). The flat electrode is enclosed in the reaction chamber with GOD to form the glucose biosensor. We propose a concept that both the GOD protein and GOD gene transformant are enclosed in the reaction chamber. One of the disc housings has an inlet in order to enclose and trap the GOD protein and GOD gene transformant in the reaction chamber. The ring filter not only enables the facile inflow of $\beta$-D-glucose (molecular weight: 180.16) to the reaction chamber, but also prevents runoff of the GOD gene transformant (cell size: $(2.0-4.0) \times(2.2-5.8) \mu \mathrm{m}^{2}$ ). Thus, the GOD protein that has lost its activity over time owing to environmental factors such as temperature and $\mathrm{pH}$ can be replaced by this newly produced GOD using the GOD gene transformant. Moreover, this transformant-based glucose biosensor is covered with a cellulose ester dialysis membrane when it is implanted (Spectra/Poa; molecular weight cut off from 12,000-14,000; Spectrum Medical Industries Inc., CA, USA). The dialysis membrane has a mechanical strength of 1-3 kgf tension.

\subsection{Time-course change in GOD activity}

Preparation of GOD gene transformant solution: the GOD gene transformant was grown in YPD agar medium containing $0.03 \%$ Zeocin for 3 days in the dark. Then, $10 \mathrm{ml}$ of YPD liquid medium was inoculated with a single colony from the YPD agar

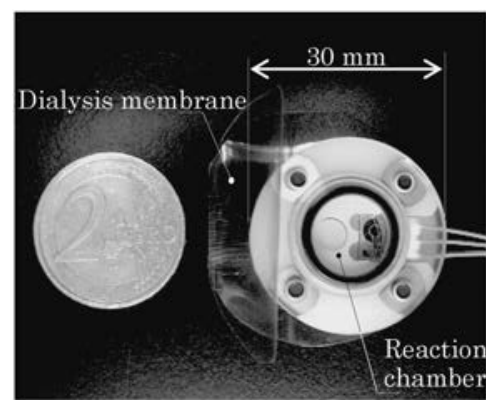

(a)

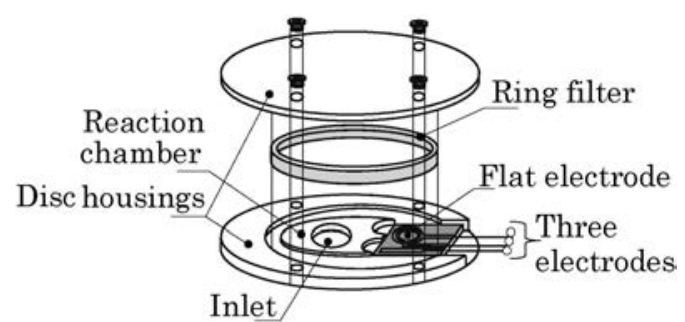

(b)

Fig. 1. Transformant-based glucose biosensor fabricated using GOD gene recombinant. Schematic diagram: (a) External view of fabricated biosensor; (b) schematic diagram. 
medium and incubated overnight with shaking (500 rpm) at $30^{\circ} \mathrm{C}$ to produce a starter culture. Next, $1 \mathrm{ml}$ of culture solution was added to $150 \mathrm{ml}$ of YPD liquid medium and cultured with shaking $(500 \mathrm{rpm})$ for $1-3$ days at $30^{\circ} \mathrm{C}$ in order to reach $1 \mathrm{U} / \mathrm{ml}$. In order to monitor the growth phase during incubation, the density of GOD gene transformant was measured at $660 \mathrm{~nm}$ using a spectrophotometer $\left(O D_{660}\right.$, Hitachi, Japan).

GOD gene transformant solutions $(1 \mathrm{U} / \mathrm{ml})$ were incubated with shaking $(500 \mathrm{rpm})$ and without shaking at $37^{\circ} \mathrm{C}$ for 2 weeks in order to evaluate the time-course changes in GOD activity produced by the GOD gene transformant (culture solution). Commercially available GOD powders from A. niger (control 1, $231 \mathrm{U} / \mathrm{mg}$, Amano Enzyme Inc., Japan; control 2,280 U/mg, Kikkoman Co., Japan) and a recombinant GOD, purified from a transformant (control 3), were purchased as the controls. The GOD powders were added to phosphoric acid buffer solution ( $\mathrm{pH} 7.0$ ) to about $1.00 \mathrm{U} / \mathrm{ml}$ and incubated at $37^{\circ} \mathrm{C}(\mathrm{GOD}$ solutions). Since it was difficult to make the initial GOD activity values identical under all conditions, the GOD activity is shown as a relative value for each measured value calculated as the ratio to its initial value as a standard (relative GOD activity).

\subsection{Detected current characteristics}

The detected current characteristics of the transformant-based glucose biosensor were evaluated in vitro. In order to make possible to compare the current characteristics of the transformant-based glucose biosensor with other glucose sensors, a commonly used flow-injection system was used for this evaluation (Fig. 2). A mixing coil was fabricated using a tube $200 \mathrm{~cm}$ in length, and it was attached in order to reduce the pulsation of the buffer solution caused by a rotary pump (U4-XV, Alitea AB, Sweden). $\beta$-D-glucose $(100 \mathrm{mg} / \mathrm{dl}$, Wako Pure Chemical Industries, Ltd.) and GOD were mixed in phosphoric acid buffer solution ( $\mathrm{pH}$ 7.0) as the sample solution (mixed sample solution). When a 40 $\mu \mathrm{l}$ sample solution is injected using a sample injector (Model 7125, Rheodyne LLC, CA, USA), it flows into the reaction chamber through the inlet. A potentiostat (Model 832A, BAS Inc., Japan) and a personal computer (Sony Co., Japan) were used to measure the detected current. When the potential of the WE is set at $+0.6 \mathrm{~V}$ (versus the $\mathrm{CE}$ ) using the

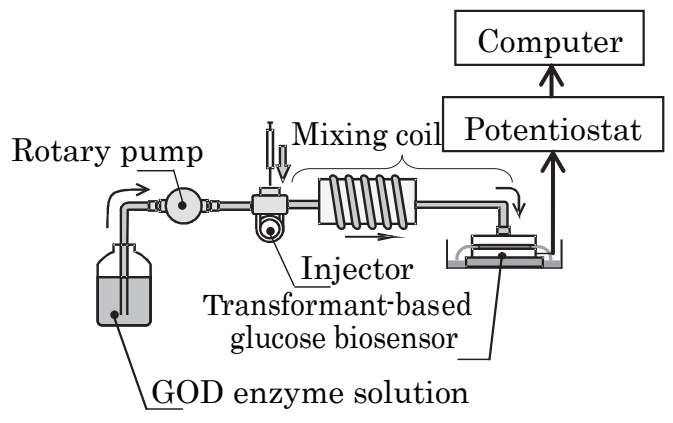

Fig. 2. Flow injection system used for evaluating current characteristics of transformant-based glucose biosensor. 
potentiostat, the detected current is converted from analog to digital by the $\mathrm{A} / \mathrm{D}$ converter (Sony Co., Japan) and is displayed and recorded by the personal computer.

A mixed sample solution was prepared using $100 \mathrm{mg} / \mathrm{dl} \beta$-D-glucose solution and commercially available GOD (control $1,231 \mathrm{U} / \mathrm{mg}$ ). The GOD activity of the mixed sample solution was adjusted to satisfy the condition that the net GOD activity in the reaction chamber $(300 \mu \mathrm{l})$ corresponded to $1 \mathrm{U}(=3.33 \mathrm{U} / \mathrm{ml}$, net GOD activity). First, the detected current dependence on flow rate was measured between $0.39-1.19 \mathrm{ml} / \mathrm{min}$.

Next, the detected current dependence on the GOD activity was measured at 0.5 , 1,2 , and $3 \mathrm{U}$ using the mixed sample solution (100 mg/dl $\beta$-D-glucose). The increase in detected current from a base line is expressed as maximum detected current $(\Delta I)$. Then, a calibration curve was measured at $1 \mathrm{U}$ and $0.79 \mathrm{ml} / \mathrm{min}$ using glucose solutions between $0-400 \mathrm{mg} / \mathrm{dl}$.

Finally, the relationship between the maximum detected current and GOD activity was measured in the range from 0 to $3 \mathrm{U}(0$ to $9.99 \mathrm{U} / \mathrm{ml})$ using the mixed sample solution with recombinant GOD purified from the GOD gene transformant $(100 \mathrm{mg} / \mathrm{dl}$ $\beta$-D-glucose, $0.79 \mathrm{ml} / \mathrm{min}$ flow rate). Commercially available GOD (control 1) was used as a control.

\section{Results}

\subsection{GOD gene transformant}

The GOD gene from $A$. niger migrates as a DNA fragment with an apparent size of 1,489-1,882 bp on electrophoresis. The single open reading frame agrees with the GOD peptide sequence of 605 amino acids in all positions in the DNA sequence analysis.

The GOD gene transformant reaches the logarithmic growth phase following an incubation period of 12 to $20 \mathrm{~h}$. The GOD activities generated by the transformant at 48 $\mathrm{h}$ (the stationary phase) and $240-600 \mathrm{~h}$ are $0.83 \mathrm{U} / \mathrm{ml}\left(O D_{660}=21.8\right)$ and $1.62 \mathrm{U} / \mathrm{ml}\left(O D_{660}\right.$ $=24.2$ ), respectively.

\subsection{Time-course change in GOD activity}

The initial GOD activities are 1.12, 1.00, 1.21, and $1.21 \mathrm{U} / \mathrm{ml}$ for controls 1, 2, 3, and the culture solution (both without and with shaking), respectively. The maximum difference between initial GOD activities was only $6 \%$. In controls 1,2 , and 3, the GOD activities decrease at 2 weeks, ranging between $32-52 \%$ of their initial values (Fig. 3). In contrast, the culture solution of the GOD gene transformant without shaking shows a small decrease in GOD activity, which is maintained at $84 \%$ for 2 weeks. Furthermore, the GOD activity is increased to $115 \%$ when the GOD gene transformant is cultured with shaking.

\subsection{Detected current characteristics}

In order to optimize the flow rate conditions within a range of $0.39-1.19 \mathrm{ml} / \mathrm{min}$, the change in detected current is measured using the commercially available GOD (control 1). The maximum detected current $(\Delta I)$ increases in proportion to flow rate, with a maximum value of $472 \mathrm{nA}$ at $0.79 \mathrm{ml} / \mathrm{min}$ (Fig. 4). The maximum detected current decreases when 


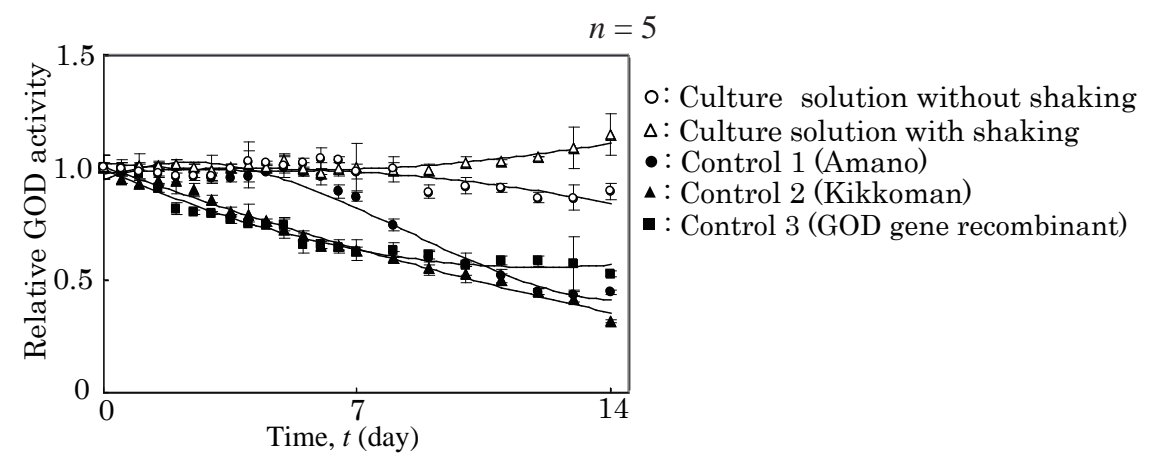

Fig. 3. Time-course changes in relative GOD activities. $n$ : number of replicates performed for each point.

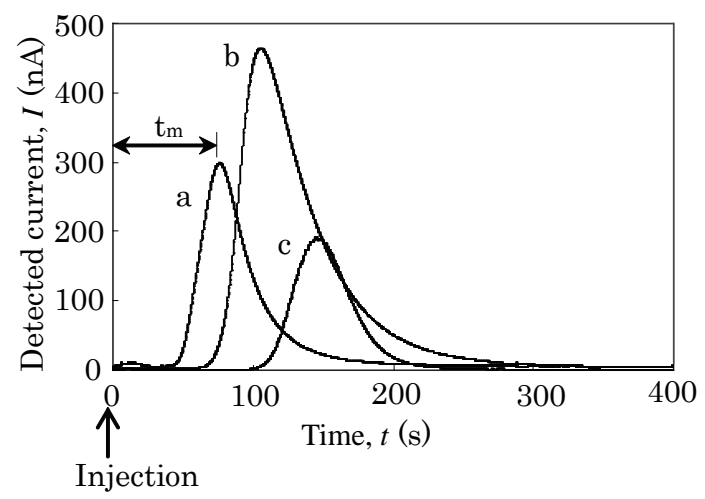

Fig. 4. Detected current characteristics with respect to flow rate in the case of using commercially available GOD; (a) $1.19 \mathrm{ml} / \mathrm{min}$ flow rate, (b) $0.79 \mathrm{ml} / \mathrm{min}$, and (c) $0.39 \mathrm{ml} / \mathrm{min}(100 \mathrm{mg} / \mathrm{dl} \beta$-Dglucose, $1 \mathrm{U}$ of net GOD activity (control 1), $40 \mu \mathrm{l}$ sample volume).

the flow rate reaches $1.19 \mathrm{ml} / \mathrm{min}$. The time from the injection to the maximum value $\left(t_{\mathrm{m}}\right)$ at $0.39,0.79$, and $1.19 \mathrm{ml} / \mathrm{min}$, are 138,99 , and $71 \mathrm{~s}$, respectively.

The maximum detected current increases in proportion to commercially available GOD activity (control 1), with a minimum value of $318 \mathrm{nA}$ at $0.5 \mathrm{U}$ and a maximum value of 1,322 nA at $3 \mathrm{U}$ (Fig. 5(a)). When the maximum detected currents are linearly extrapolated, the slope is $466.8 \mathrm{nA} / \mathrm{U}$, the $y$-intercept is 56.5 , and the $R^{2}$ is $0.93(n=5$, Fig. 5(b)).

A calibration curve for the glucose biosensor fabricated using the commercially available GOD (control 1) is obtained with a slope of 4.42, a $y$-intercept of 23.84, a $R^{2}$ of 0.96, and relative standard deviations (RSDs) of $4.3-11.8 \%(n=3$, Fig. 6$) . R^{2}$ and RSD 


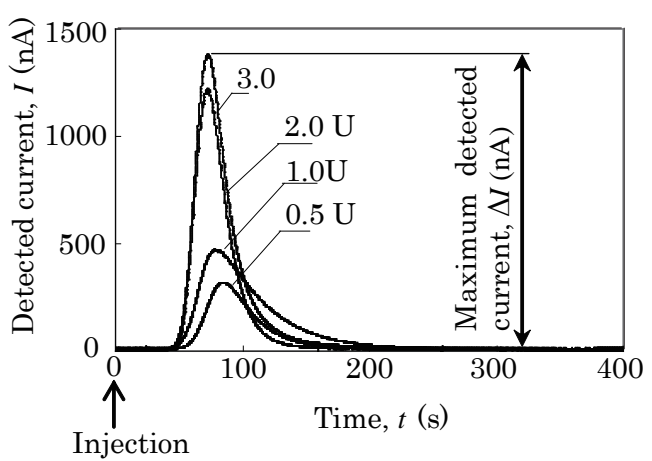

(a)

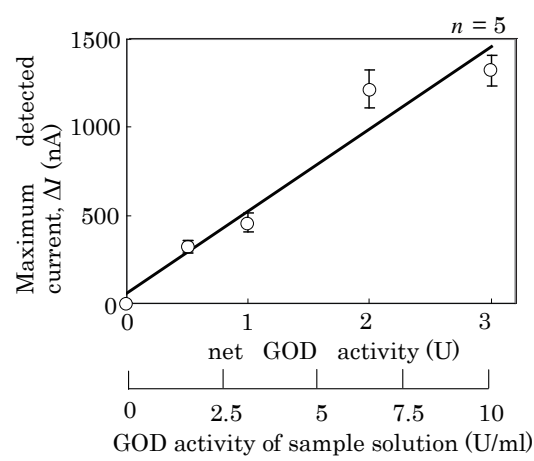

(b)

Fig. 5. Detected current characteristics with respect to commercially available GOD enzymatic activity (control 1,100 mg/dl $\beta$-D-glucose, $0.79 \mathrm{ml} / \mathrm{min}$ flow rate, $40 \mu \mathrm{l}$ sample volume): (a) Timecourse change; (b) calibration curve of maximum detected current.

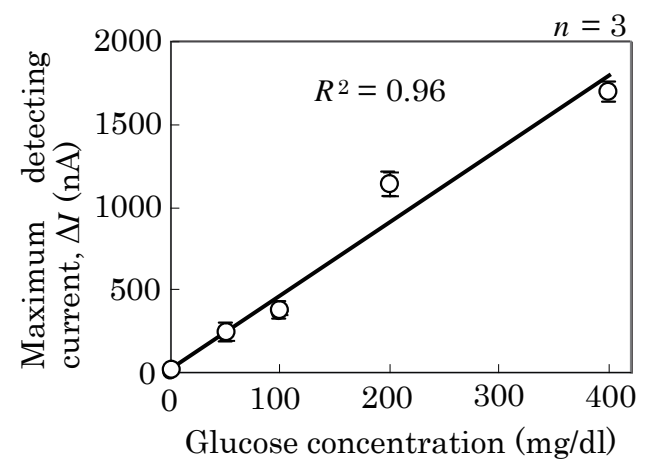

Fig. 6. Calibration curve at $1 \mathrm{U}$ of commercially available GOD (control 1), $0.79 \mathrm{ml} / \mathrm{min}, 40 \mu \mathrm{l}$ sample solution.

indicate favorable results.

The relationship between maximum detected current and GOD activity determined using the recombinant GOD for the transformant-based glucose biosensor is obtained with a slope of $237.9 \mathrm{nA} / \mathrm{U}, y$-intercept of 70.0, and $R^{2}$ of 0.53 (Fig. 7). $100 \mathrm{nA}$ can be obtained at $0.42 \mathrm{U}$ using the recombinant GOD. 


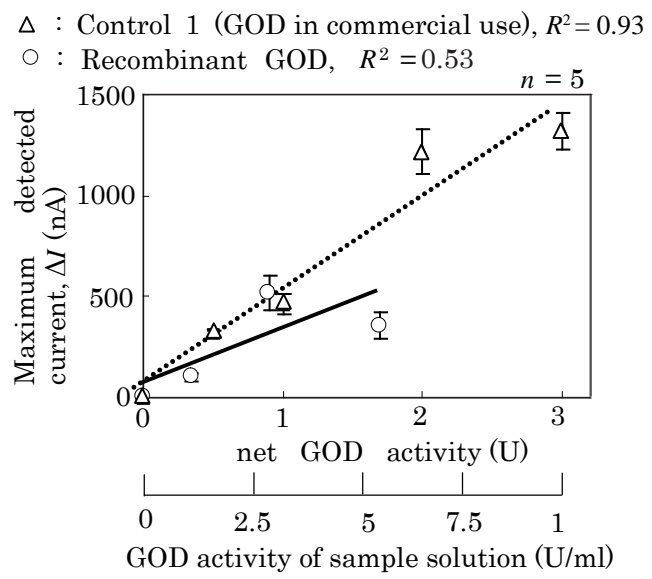

Fig. 7. Relationship between maximum detected current and GOD activity using recombinant GOD (100 mg/dl $\beta$-D-glucose, $0.79 \mathrm{ml} / \mathrm{min}$ flow rate, $40 \mu \mathrm{l} \mathrm{sample} \mathrm{volume).}$

\section{Discussion}

We proposed a novel transformant-based glucose biosensor in order to solve deactivation of the enzyme with time.

The gene for A. niger GOD has been cloned in this study. This conclusion is based on the following: first, the ligated DNA corresponded to a 1,489-1,882 bp fragment, as determined by electrophoresis, close to the size of GOD, 1,818 bp. Second, the single open reading frame encoded a protein of 605 amino acids corresponding to the size predicted by others. ${ }^{(17)}$ Third, the clones were cultured and secreted a protein, which had the GOD activity of catalyzing $\beta$-D-glucose oxidation. Thus, we successfully obtained the GOD gene transformant (yeast) that can produce not only secretory expression but also constitutive expression.

In order to evaluate the effects of temperature on GOD activity when a glucose biosensor is implanted into the body, we incubated the GOD solution at $37^{\circ} \mathrm{C}$, and found that GOD activity decreases to less than one half of the initial value by 2 weeks. Previously, Nakamura and Hayashi(34) evaluated GOD activity for only 16 h using purified GOD from A. niger. Our decreased stability was not significantly different from their previously reported results, in which GOD activity decreased to approximately $10 \%$ its initial value at $16 \mathrm{~h}$. One explanation for this phenomenon can be that the enzyme concentration might not be optimal. It is considered that addition of extra GOD alone cannot recover the lost GOD activity in a totally implantable glucose biosensor because deactivation of GOD is too much to maintain high measurement accuracy. On the other hand, GOD activity increases to $115 \%$ in the case of culture solution with shaking. It is considered that the multiplication rate of the GOD gene transformant might be increased because the dissolved oxygen concentration of culture solution increased with shaking. In the current study, the culture solution of the GOD gene transformant without shaking 
may be closest to the conditions of a glucose biosensor implanted into the body. These results suggest a possibility, if the enzyme is initially enclosed in the supersaturation state of activity, that enclosing both the GOD protein and GOD gene transformant in a glucose biosensor may prevent the decreasing GOD activity over a long time.

It is considered that when the flow rate is increased to $1.19 \mathrm{ml} / \mathrm{min}$ or higher, the reaction time is shortened, and as a result the maximum detected current becomes small. The main factor for determining the optimum flow rate is the place where a real glucose biosensor is implanted in the human body. Since a totally implantable glucose biosensor has not yet been developed for practical use, the exact response time optimal for precise measurements is not defined, but it can be estimated that approximately $1 \mathrm{~min}$ may be required. Shibata and Kamiya determined that the capillary red cell velocity is $0.024 \mathrm{~cm} / \mathrm{s}$, the capillary density is 40,000 line $/ \mathrm{cm}^{2}$, and diameter of the capillary vessel is $5 \mu \mathrm{m} .{ }^{(35)}$ Therefore, the flow rate of capillary blood per $100 \mathrm{~g}$ muscle mass can be estimated as $1 \mathrm{ml} / \mathrm{min} / 100 \mathrm{~g}$. In order to improve the response of the glucose biosensor, the glucose sensor should be implanted into the muscle tissue where capillary vessels are densely distributed so that blood can easily flow into the glucose sensor.

The detected current is dependent on GOD activity with $466.8 \mathrm{nA} / \mathrm{U}$ when using commercially available GOD. Since the maximum detected current needed for a glucose biosensor in commercial use has been shown to be approximately $100 \mathrm{nA},{ }^{(36)}$ more than $0.21 \mathrm{U} / \mathrm{ml} \mathrm{GOD}$ is sufficient for a transformant-based glucose biosensor. The in vitro evaluation demonstrated the possibility of a glucose biosensor, enabling the detection of concentrations of glucose of $0-400 \mathrm{mg} / \mathrm{dl}$ with a $R^{2}$ of 0.96 .

The maximum detected current is also dependent on GOD activity with $237.9 \mathrm{nA} / \mathrm{U}$ even when the recombinant GOD is used. The maximum detected current of the recombinant GOD in this study is almost half of that of the native (commercial available) protein (control 1). It is speculated that this decrease in GOD activity and decrease in $R^{2}$ of the recombinant GOD may be caused by other proteins produced by the GOD gene transformant. Thus, it is suggested that more than $0.42 \mathrm{U}$ of GOD will be sufficient for enclosing in the transformant-based glucose biosensor.

\section{Conclusion}

Our results indicated that (i) the GOD gene transformant, which is capable of not only secretory expression but also constitutive expression, was obtained, and (ii) deactivated GOD, with time, can be replaced with a newly produced recombinant GOD from the GOD gene transformant. If the GOD gene transformant is enclosed in the reaction chamber, immobilization of the enzyme is not required, suggesting that it is possible to develop a totally implantable glucose biosensor for practical use with high applicability to organisms.

\section{Acknowledgements}

The authors thank Mr. Kenichi Yanai and Mr. Shinji Nanba at Research Laboratories, Denso Co. for assistance in fabrication of the flat electrode. 


\section{References}

1 J. D. Newman, P. J. Warner, A. P. F. Turner and L. J. Tigwell: Biosensors: A clearer view (Cranfield University, UK, 2004) p. 216.

2 J. D. Newman and A. P. F. Turner: Biosens. Bioelectron. 20 (2005) 2435.

3 C. Taylor, G. Kenausis, I. Katakis and A. Heller: J. Electroanal. Chem. 396 (1995) 511.

4 M. Gerritsen, J. A. Jansen, A. Kros, R. J. M. Nolte and J. A. Lutterman: J. Invest. Surg. 11 (1998) 163.

5 J. Mastrototaro: J. Pediatr. Endocrinol. Metab. 12 (1999) 751.

6 M. C. Frost and M. E. Meyerhoff: Curr. Opin. Chem. Biol. 6 (2002) 633.

7 J. Q. Brown, R. Srivastava and M. J. McShane: Biosens. Bioelectron. 21 (2005) 212.

8 B. Yu, Y. Moussy and F. Moussy: Front. Biosci. 1 (2005) 512.

9 D. D. Zhou and R. J. Greenberg: Front. Biosci. 1 (2005) 166.

10 M. Lei, A. Baldi, E. Nuxoll, R. A. Siegel and B. Ziaie: Diabetes Technol. Ther. 8 (2006) 112.

11 S. K. Garg, S. Schwartz and S. V. Edelman: Diabetes Care 27 (2004) 734.

12 G. S. Wilson and R. Gifford: Biosens. Bioelectron. 20 (2005) 2388.

13 U. Klueh and D. L. Kreutzer: Diabetes Technol. Ther. 7 (2005) 727.

14 R. Gifford, J. J. Kehoe, S. L. Barnes, B. A. Kornilayev, M. A. Alterman and G. S. Wilson: Biomaterials 27 (2006) 2587.

15 C. A. Quinn, R. E. Connor and A. Heller: Biomaterials 18 (1997) 1665.

16 K. J. Ziegler: Trends Biotechnol. 23 (2005) 440.

17 K. R. Frederick, J. Tung, R. S. Emerick, F. R. Masiarz, S. H. Chamberlain, A. Vasavada and S. Rosenberg: J. Biol. Chem. 265 (1990) 3793.

18 A. D. Baetselier, P. Dohet, M. D. Beukelaer, V. Ha-Thi, J. Hanotier, K. Frederick, S. Rosenberg and A. Vasavada: J. Biotechnol. 24 (1992) 141.

19 C. F. B. Witteveen, P. J. I. van de Vondervoort, H. C. van den Broeck, F. A. C. van Engelenburg, L. H. de Graaff, M. H. B. C. Hillebrand, P. J. Schaap and J. Visser: Curr. Genet. 24 (1993) 408.

20 F. R. Murray, D. J. Llewellyn, W. J. Peacock and E. S. Dennis: Curr. Genet. 32 (1997) 367.

21 A. Baetselier, A. Vasavada, P. Dohet, V. Ha-Thi, M. D. Beukelaer, T. Erpicum, L. D. Clerck, J. Hanotier and S. Rosenberg: Biotechnology 9 (1991) 559.

22 J. Hill, K. A. Ian, G. Donald and D. E. Griffiths: Nucleic. Acids. Res. 19 (1991) 5791.

23 A. Kapat, J.-K. Jung and Y.-H. Park: J. Appl. Microbiol. 90 (2001) 216.

24 J.-H. Ko, M. S. Hahm, H. A. Kang, S. W. Nam and B. H. Chung: Protein Expr. Purif. 25 (2002) 488.

25 G. H. Chen, S. J. Tang, C. S. Chen and S. T. Jiang: J. Agric. Food Chem. 49 (2001) 641.

26 C. P. Kurtzman, J. W. Fell eds.: The yeast, a taxonomic study, fourth edition (Elsevier Science B.V., Amsterdam, 1998) p. 331.

27 H. R. Waterham, M. E. Digan, P. J. Koutz, S. V. Lair and J. M. Cregg: Gene 186 (1997) 37.

28 P. Perez, G. Tiraby, J. Kallerhoff and J. Perret: Plant Mol. Biol. 13 (1989) 365.

29 A. K. Jhingan: Methods in Molecular and Cellular Biology 3 (1992) 15.

30 J. Sambrock, E. F. Fritsch and T. Maniatis: Molecular Cloning, a Laboratory Manual, second edition (Cold Spring Harbor, NY, 1989) p. 1.

31 K. Hayashi, M. Nakazawa, Y. Ishizaki, N. Hiraoka and A. Obayashi: Nucleic. Acids. Res. 14 (1986) 7617.

32 E. Neumann, M. S.-Ridder, Y. Wang and P. H. Hofschneider: EMBO J. 1 (1982) 841.

33 R. D. Gietz and R. A. Woods: BioTechniques 30 (2001) 816.

34 S. Nakamura and S. Hayashi: FEBS Lett. 41 (1974) 327.

35 M. Shibata and A. Kamiya: Microvasc. Res. 30 (1985) 333.

36 G. Rao, P. Glikfeld and R. H. Guy: Pharm. Res. 10 (1993) 1751. 